\title{
Two deeply divergent mitochondrial clades in the wild mouse Mus macedonicus reveal multiple glacial refuges south of Caucasus
}

\author{
A Orth ${ }^{1}, \mathrm{~J}-\mathrm{C}$ Auffray ${ }^{2}$ and F Bonhomme ${ }^{1}$ \\ ${ }^{1}$ Laboratoire Génome Populations Interactions, UMR 5000 CNRS, CC063, Universifé Montpellier 2, 34095 Montpellier cedex 05, \\ France; ${ }^{2}$ Institut des Sciences de l'Evolution, UMR 5554 CNRS, CC 064, Université Montpellier 2, 34095 Montpellier cedex, \\ France
}

A survey of 77 individuals covering the range of Mus macedonicus from Georgia in the East to Greece and Bulgaria in the West and Israel in the South has shown the existence of two deeply divergent mitochondrial clades. The southern clade was until now undetected and characterises mice from Israel. Nuclear genes also show some amount of regional differentiation tending to separate the southern $M$. macedonicus from the northern ones. These results point towards the fact that the eastern Mediterranean short-tailed mouse, which was seen as a fairly homogeneous monotypic species, has in fact a more complex phylogeographic history than has been suspected, and that it warrants the existence of two subspecies. The reasons for this non-uniformity probably ought to be looked for in the history of faunal movements linked to glacial periods, underlining the possible existence of at least two refugia south of the Caucasus.

Heredity (2002) 89, 353-357. doi:10.1038/sj.hdy.6800147

Keywords: mitochondrial divergence; subspecies; Mus macedonicus; M. macedonicus spretoides; glacial refuges

\section{Introduction}

The House Mouse species complex has attracted many genetic studies aimed at deciphering its systematic and phylogeographic structure over the last 20 years. Recently, a report by Gündüz et al (2000) in this journal has thrown some light on the genetic make up of one of its component, the eastern Mediterranean short-tailed mouse Mus macedonicus, over the northern part of its range. The mitochondrial DNA analysis of these authors revealed no spatial heterogeneity of mtDNA haplotypes over their sampling, they thus considered M. macedonicus as monotypic. Here, we extend the geographic coverage over the whole species range and, in a similar analysis, reveal that the $M$. macedonicus populations from Israel belong to a quite divergent clade, and hence that the species probably has a more complex history than suspected. We also summarise and extend the available nuclear gene (electrophoretic) and morphological data to document other aspects of geographical differentiation in this species. According to the level of genetic divergence observed, two distinct subspecies should be recognised.

\section{Materials and methods}

Various samples collected over the years by our laboratory were typed for mitochondrial D-Loop nucleotide

Correspondence: A Orth, Laboratoire Génome, Populations et Interactions, UMR 5000 CNRS, CC063, Université Montpellier 2, 34095 Montpellier cedex 05, France.

E-mail: a-orth@crit.univ-montp2.fr

Received 27 December 2001; accepted 7 May 2002 variation after PCR amplification and sequencing. The primers used were defined as being at positions $\mathrm{H} 41$ and L15372 of the domesticus DNA reference sequence Bibb et al (1981), and yielded a slightly bigger fragment than the one used by Gündüz et al (2000). Altogether, a 733 bp fragment (between position 15424 and 16283) common to both studies and encompassing $94 \%$ of the D-Loop was aligned for 12 new M. macedonicus individuals. Additionally, six M. macedonicus sequences available in GenBank were included in our analysis. Five sequences pertaining to $M . m$. musculus, seven to $M$. $m$. domesticus, one to $M$. spicilegus and one to $M$. spretus were used as outgroups, of which six were extracted from GenBank, and eight sequenced for this project. The origins and GenBank accession numbers for each sequence are reported in Table 1. The geographic origin of samples of M. macedonicus used in this study is depicted in Figure 1 (GenBank accession numbers AF506180-AF506199).

The sequence data were transformed in a Kimura 2parameter distance matrix (with a ts/tv of 1.2) and subjected to phylogenetic analysis with the neighbor-joining algorithm as implemented by the PHYLIP package (Felsenstein 1993). Bootstrap values were obtained after 1000 replications (Figure $2 \mathrm{a}$ ).

Published electrophoretical data at 27 loci (as reported in Bonhomme et al, 1983) were supplemented with samples from of Israel (Haifa, $n=8$ ) and Georgia (Lagodekhi $n=27$, Lissi $n=20$, Chirakskaya $n=7$ ) processed in the same way. The same two M. m. domesticus and M. m. musculus samples (Bonhomme et al, 1983) were used as outgroups. Eleven loci were polymorphic in the data set. Nei's genetic distance was computed over the 27 loci, and a neighbor-joining tree with bootstrap values 
Table 1 Geographic coordinates of samples and origin of data

\begin{tabular}{|c|c|c|c|c|c|c|}
\hline Map locality & Locality & $\begin{array}{l}\text { Mitochondrial } \\
\text { haplotype } \\
(\text { Fig 2a) }\end{array}$ & $\begin{array}{l}\text { Nuclear } \\
\text { genome } \\
(\text { Fig 2b) }\end{array}$ & Species & GenBank & Latitude/Longitude \\
\hline 1 & Haifa & & Israel & macedonicus & & $32^{\circ} 49^{\prime} \mathrm{N} 35^{\circ} 0^{\prime} \mathrm{E}$ \\
\hline 2 & Jerusalem1 & Israel 1 & & macedonicus & this report & $31^{\circ} 46 \mathrm{~N} 35^{\circ} 13^{\prime} \mathrm{E}$ \\
\hline 2 & Jerusalem1 & Israel 2 & & macedonicus & this report & $31^{\circ} 46 \mathrm{~N} 35^{\circ} 13^{\prime} \mathrm{E}$ \\
\hline 2 & Jerusalem1 & Israel 3 & & macedonicus & this report & $31^{\circ} 46 \mathrm{~N} 35^{\circ} 13^{\prime} \mathrm{E}$ \\
\hline 2 & Jerusalem2 & Israel 4 & & macedonicus & this report & $32^{\circ} 43^{\prime} \mathrm{N} 35^{\circ} 03^{\prime} \mathrm{E}$ \\
\hline 3 & Dor & Israel 5 & & macedonicus & this report & $32^{\circ} 38^{\prime} \mathrm{N} 34^{\circ} 56^{\prime} \mathrm{E}$ \\
\hline 4 & Poriyya & Israel 6 & & macedonicus & this report & $32^{\circ} 42^{\prime} \mathrm{N} 35^{\circ} 37^{\prime} \mathrm{E}$ \\
\hline 5 & Lissi & & Georgia & macedonicus & & $41^{\circ} 44^{\prime} \mathrm{N} 44^{\circ} 47^{\prime} \mathrm{E}$ \\
\hline 6 & Lagodekhi & Georgia 1 & & macedonicus & this report & $41^{\circ} 49^{\prime} \mathrm{N} 46^{\circ} 16^{\prime} \mathrm{E}$ \\
\hline 6 & Lagodekhi & Georgia 2 & & macedonicus & this report & $41^{\circ} 49^{\prime} \mathrm{N} 46^{\circ} 16^{\prime} \mathrm{E}$ \\
\hline 6 & Lagodekhi & Georgia 3 & & macedonicus & this report & $41^{\circ} 49^{\prime} \mathrm{N} 46^{\circ} 16^{\prime} \mathrm{E}$ \\
\hline 6 & Lagodekhi & Georgia 4 & Lagodekhi & macedonicus & this report & $41^{\circ} 49^{\prime} \mathrm{N} 46^{\circ} 16^{\prime} \mathrm{E}$ \\
\hline 7 & Chirakskaya & Georgia 5 & Chirakskaya & macedonicus & this report & $41^{\circ} 22^{\prime} \mathrm{N} 46^{\circ} 21^{\prime} \mathrm{E}$ \\
\hline 8 & Arak city & Iran 1 & & macedonicus & AJ286328 & $34^{\circ} 04^{\prime} \mathrm{N} 49^{\circ} 43^{\prime} \mathrm{E}$ \\
\hline 9 & Kermanshah & Iran 2 & & macedonicus & AJ286329 & $34^{\circ} 27^{\prime} \mathrm{N} 47^{\circ} 53^{\prime} \mathrm{E}$ \\
\hline 10 & Kayseri & Turkey 3 & & macedonicus & AJ286327 & $38^{\circ} 43^{\prime} \mathrm{N} 35^{\circ} 29^{\prime} \mathrm{E}$ \\
\hline 11 & Samsun & Turkey 1 & & macedonicus & AJ286325 & $41^{\circ} 19^{\prime} \mathrm{N} 36^{\circ} 19^{\prime} \mathrm{E}$ \\
\hline 11 & Samsun & Turkey 2 & & macedonicus & AJ286326 & $41^{\circ} 19^{\prime} \mathrm{N} 36^{\circ} 19^{\prime} \mathrm{E}$ \\
\hline 12 & Orizare & & Bulgaria & macedonicus & & $42^{\circ} 45^{\prime} \mathrm{N} 27^{\circ} 37^{\prime} \mathrm{E}$ \\
\hline 13 & Jitarovo & Bulgaria 1 & & macedonicus & this report & $42^{\circ} 38^{\prime} \mathrm{N} 27^{\circ} 18^{\prime} \mathrm{E}$ \\
\hline 14 & Gradsko & Macedonia & & macedonicus & U47535 & $41^{\circ} 25^{\prime} \mathrm{N} 22^{\circ} 40^{\prime} \mathrm{E}$ \\
\hline 15 & Kranevo & & & macedonicus & & $43^{\circ} 8^{\prime} \mathrm{N} 27^{\circ} 55^{\prime} \mathrm{E}$ \\
\hline \multirow[t]{15}{*}{16} & Langadhas & & Greece & macedonicus & & $40^{\circ} 46^{\prime} \mathrm{N} 23^{\circ} 5^{\prime} \mathrm{E}$ \\
\hline & Jerusalem2 & Israel 8 & & domesticus & this report & $32^{\circ} 43^{\prime} \mathrm{N} 35^{\circ} 03^{\prime} \mathrm{E}$ \\
\hline & Keshet & Israel 9 & & domesticus & this report & $33^{\circ} 01^{\prime} \mathrm{N} 35^{\circ} 42^{\prime} \mathrm{E}$ \\
\hline & Ortal & Israel 10 & & domesticus & this report & $33^{\circ} 03^{\prime} \mathrm{N} 35^{\circ} 45^{\prime} \mathrm{E}$ \\
\hline & Ortal & Israel 11 & & domesticus & this report & $33^{\circ} 03^{\prime} \mathrm{N} 35^{\circ} 45^{\prime} \mathrm{E}$ \\
\hline & Batumi & Georgia 7 & & domesticus & U47496 & $41^{\circ} 38^{\prime} \mathrm{N} 41^{\circ} 39^{\prime} \mathrm{E}$ \\
\hline & Batumi & Georgia 8 & & domesticus & U47497 & $41^{\circ} 38^{\prime} \mathrm{N} 41^{\circ} 39^{\prime} \mathrm{E}$ \\
\hline & Chirakskaya & Georgia 9 & & domesticus & this report & $41^{\circ} 22^{\prime} \mathrm{N} 46^{\circ} 21^{\prime} \mathrm{E}$ \\
\hline & Batumi & Georgia 10 & & musculus & U47532 & $41^{\circ} 38^{\prime} \mathrm{N} 41^{\circ} 39^{\prime} \mathrm{E}$ \\
\hline & Didish-shiraki & Georgia 11 & & musculus & this report & $41^{\circ} 14^{\prime} \mathrm{N} 46^{\circ} 33^{\prime} \mathrm{E}$ \\
\hline & Lagodekhi & Georgia 12 & & musculus & this report & $41^{\circ} 49^{\prime} \mathrm{N} 46^{\circ} 16^{\prime} \mathrm{E}$ \\
\hline & Vashlavan & Georgia 13 & & musculus & this report & $41^{\circ} 7^{\prime} \mathrm{N} 46^{\circ} 28^{\prime} \mathrm{E}$ \\
\hline & Kishinev & Moldavia & & musculus & U47533 & $47^{\circ} 0^{\prime} \mathrm{N} 28^{\circ} 50^{\prime} \mathrm{E}$ \\
\hline & Halbturn & Austria & & spicilegus & U47536 & $47^{\circ} 52^{\prime} \mathrm{N} 16^{\circ} 59^{\prime} \mathrm{E}$ \\
\hline & Cadiz & Spain & & spretus & U47539 & $36^{\circ} 32^{\prime} \mathrm{N} 6^{\circ} 17^{\prime} \mathrm{W}$ \\
\hline
\end{tabular}

obtained after 1000 replications was produced as above (Figure 2b).

The morphological variation within M. macedonicus was analysed by a geometric morphometric approach on the skull of 33 adult individuals originating from Israel $(n=10)$, Bulgaria $(n=5)$ and Georgia $(n=18)$. Thirteen landmarks were digitised on the left side of the ventral view of skulls. Individual size was estimated by the centroid size of landmarks configurations. These configurations were superimposed following the GLS (Procrustes) procedure described in Rohlf and Slice (1990). A PCA was performed on the residuals of all coordinates after superimposition. The differences in size among the three samples were tested using ANOVAs on centroid size. Shape disparity was assessed by MANOVAs on the first eight PCs (accounting for 82.9\% of the cumulative variance). The relationships between size and shape were determined by a multiple regression of centroid size on the first eight PCs.

\section{Results and discussion}

The tree in Figure 2a shows a highly significant and clear dichotomy among the macedonicus haplotypes, with the
Israeli group (clade B) well separated from all other (clade A), extending the results of Gündüz et al (2000). Clade A does not contain any robust phylogeographic information, despite the fact that our sample encompasses animals trapped further East in the Caucasus (Orth et al, 1996) than those previously analysed. A slight tendency for geographic grouping may nevertheless be seen (Figure 2a), indicating that the sequences may have started to evolve in situ. The average nucleotide divergence between clades A and B was $2.9 \%$, which is of the same order as, for instance, the domesticusmusculus divergence (3.8\%), dated around 0.5 Myrs (Boursot et al, 1993). It also represents about half the average divergence between $M$. macedonicus and its northernmost sibling species, M. spicilegus (4.4\%). As for the nuclear genome, Figure $2 \mathrm{~b}$ shows that the Israeli population clearly belongs to the macedonicus clade, but with a clear divergence from the other samples.

The electrophoretical survey of Israeli, Georgian, Greek and Bulgarian specimens yielded a Nei's genetic distance of 0.011 only between the Caucasus and Europe, but 0.048 and 0.073 between each respectively and Israel. These values are substantial but still small as compared for instance to 0.247 found between $M$. musculus 


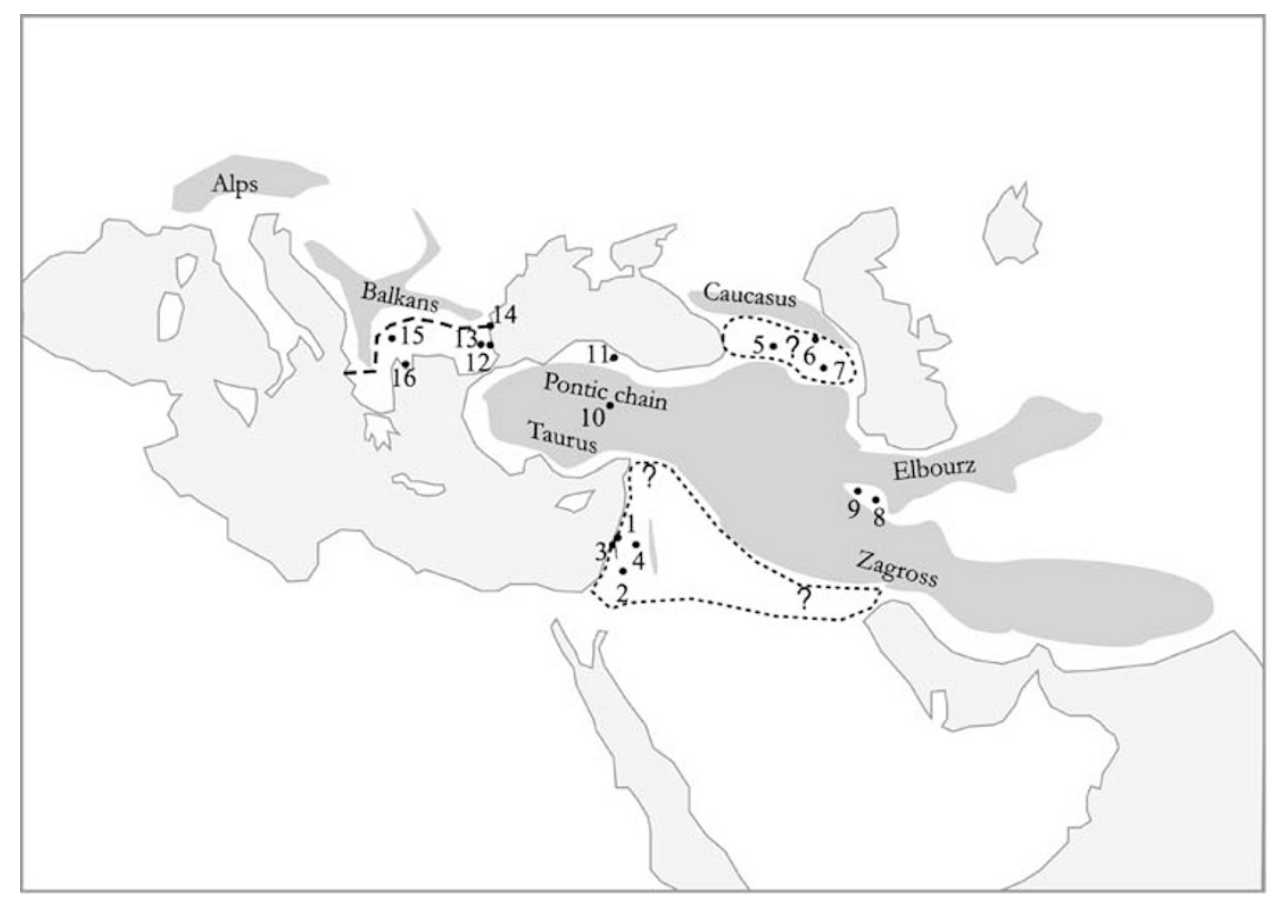

Figure 1 Sampling locations for Mus macedonicus. Grey: mountains over $1000 \mathrm{~m}$ elevation; dashed line: European northern limit of M. macedonicus (= southern limit for M. spicilegus); dotted line: potential refugia for both M. macedonicus subspecies.

domesticus and M. musculus musculus samples over the same loci (Bonhomme et al, 1983 and unpublished data). The genetic differentiation between the Haifa and other M. macedonicus samples was primarily due to loci Aat1, Es1, Mpi, Mod1 and Pgm1, this last locus being almost fixed for an alternative allele.

The centroid size did not differ between M. macedonicus of Bulgaria and Georgia $\left(F_{[1,21]}=0.67 ; \mathrm{NS}\right)$, but it did differ significantly between these two groups, pooled together, and the Israeli sample $\left(F_{[1,31]}=13.88 ; P<0.001\right)$. In agreement with Bergman's rule, Israeli mice appear to be smaller. Concerning the shape of the skull, Bulgarian and Georgian groups were pooled since they were undistinguishable on the first eight PCs (Wilk's lambda ${ }_{[8,14]}=$ 0.58; NS). This high morphological similarity of the northern $M$. macedonicus has already been demonstrated on cranial and dental traits by Krystufek and Macholan (1998) on three samples from Europe and Asia Minor. In our study, the group formed by the northern-most samples is different from the Israeli sample (Wilk's $\left.\operatorname{lambda}_{[8,24]}=0.29 ; P \ll 0.001\right)$. However, the strong relationships between size and shape considering the first PC (Figure 3$)$ or the first eight PCs $\left(F_{[8,24]}=10.48 ; P \ll\right.$ $0.001)$ suggests that the differentiation in shape between the two groups might primarily reflect difference in size and the related allometric pattern. The examination of the shape difference between the two groups (Figure 3), although significant, is hardly detectable by eye, suggesting that no character on the ventral view of skull may be easily used by systematicists to distinguish the two groups. Yet, differences in the morphology of the skull between Israeli and Bulgarian mice were detected by a multivariate approach by Gerasimov et al (1990). In this case, however, the discrimination also involved a complex combination of several morphological variables rather than a limited number of characters. Morphology is known to be extremely conservative in the whole subgenus Mus (Gerasimov et al, 1990), M. macedonicus does not constitute an exception. Size remains the principal morphological trait suitable to distinguish between the northern and southern forms of $M$. macedonicus.

Concerning karyotypes as well, there are indications of significant differences between Israeli and Transcaucasian animals. Ivanitskaya et al (1996) report a higher number of NORs and an enlarged block of heterochromatin on the $\mathrm{X}$ chromosome in the southern form.

Altogether, these results argue in favour of M. macedonicus being a polytypic taxon, like $M$. musculus. Although the morphological difference between the two groups remains subtle, the clear genetic differentiation detected here suggests that they deserve to be considered as valid subspecies with Linnean trinomials. The northern group should naturally be called $M$. macedonicus macedonicus since the type specimen is from Macedonia (M. hortulanus macedonicus Petrov and Ruzic (1983), see also Harrison and Bates (1991)) while the southern form should be $M$. macedonicus spretoides according to the first descriptions of this species in Israel (M. spretoides, Auffray et al (1988), Bates and Harrison (1989), Auffray et al (1990)).

The origin of these two subspecies and the two divergent mitochondrial clades they harbour should be looked at in recent history, and this points towards the existence of two separate glacial refuges. It is striking to note that the pattern we observe here is quite similar to that reported by Seddon et al (2001) for the European hedgehog (Erinaceus concolor). In this case, there is a clear distinction between Turkish (Anatolian) and Israeli mitotypes (boostrap value 94\%) within their clade C2. On the other hand these authors report a more divergent clade in eastern Europe (clade C1). This situation mimics the one found between the two sibling mouse species $M$. spicilegus and M. macedonicus: $M$. spicilegus, the mound- 


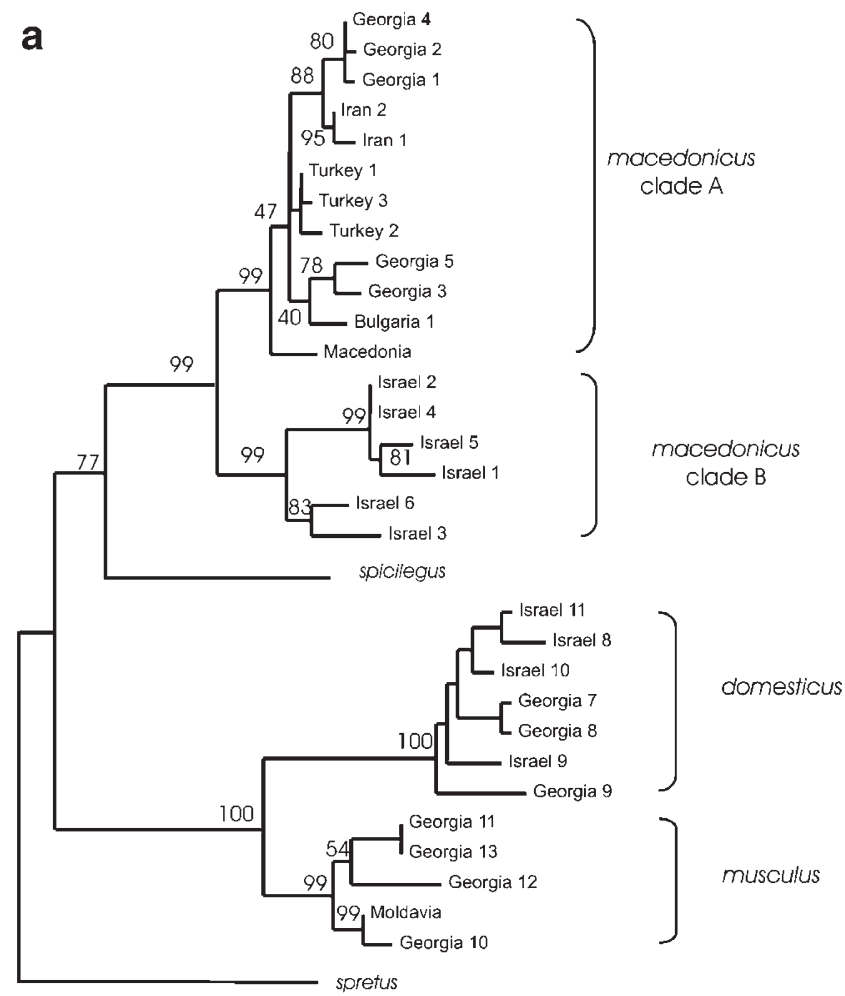

$\overline{1 \% \text { nucleotide divergence }}$

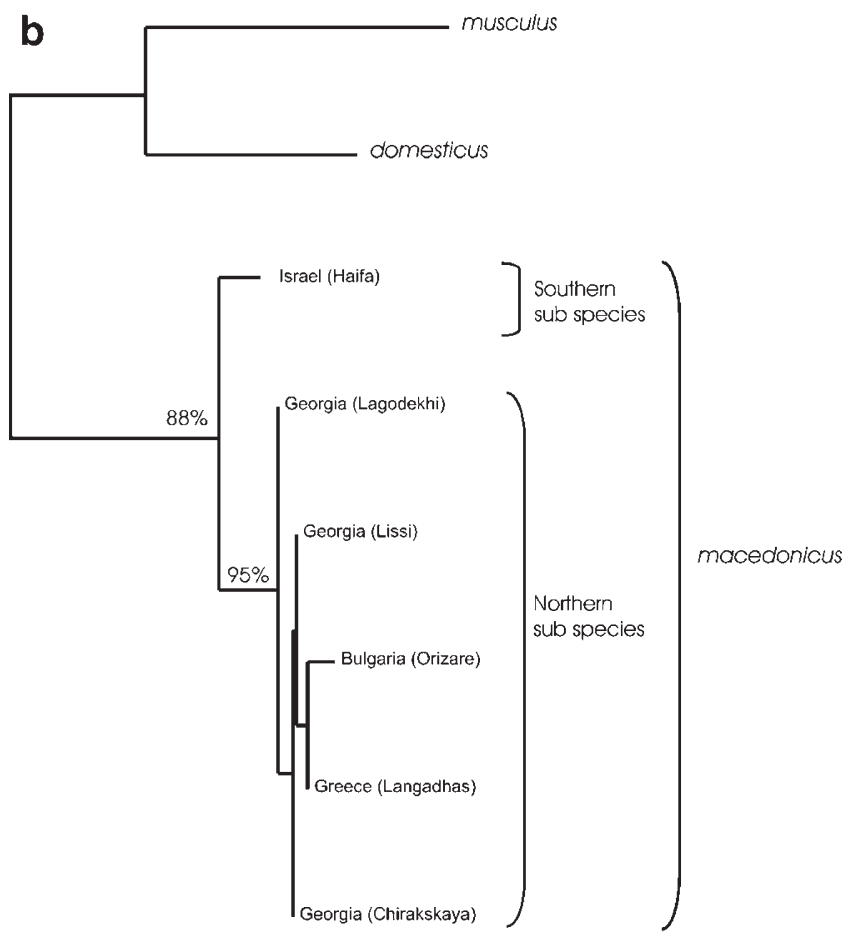

0.1 Nei's distance

Figure 2 (a) Phylogeny of the mitochondrial DNA haplotypes (see Table 1 for details about localities). The tree is rooted with the Mus spretus sequence. The bootstrap values were obtained after 1000 replications. (b) Phylogeny obtained with nuclear electrophoretical data, Neighbour-joining tree with bootstrap values after 1000 replications.

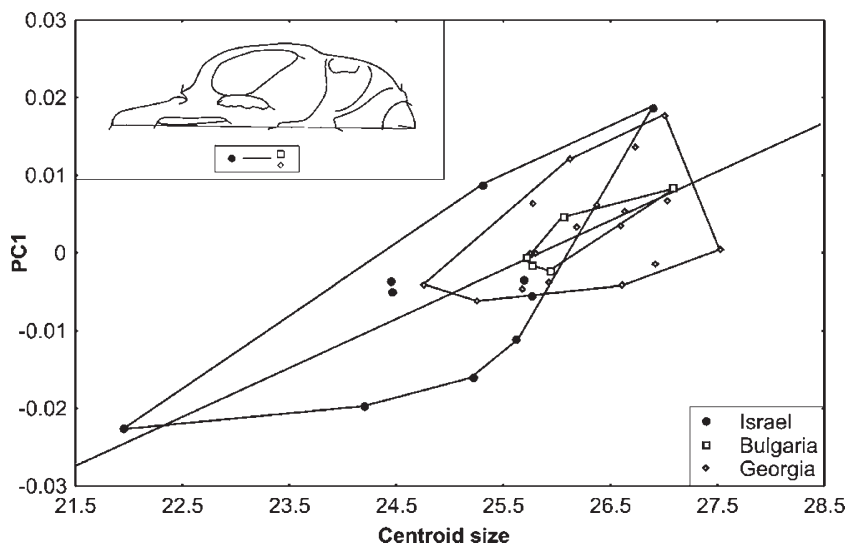

Figure 3 Plot of centroid size of skulls against their score on the first principal component (PC1) performed on Procrustes residuals (GLS superimposition). On the ventral view of skull, the vectors at each landmark (magnified six times in order to be visible) express the morphological changes from the Israeli mean shape to that of Bulgarian and Georgian material.

building mouse, whose mitochondrial DNA is closely related but clearly divergent from that of $M$. macedonicus (Figure 2a) would be the European form corresponding to clade $\mathrm{C} 1$ in E. concolor, and M. macedonicus would encompass two divergent clades (A and B, Figure 2a), corresponding to the two Asian subclades in E. concolor $\mathrm{C} 2$. The only substantial difference resides in the fact that the limit between macedonicus and spicilegus is found in Europe (as shown in Figure 1) while the C1/C2 contact in E. concolor occurs at the Marmara Sea (Seddon et al 2001).

The present results thus confirm the existence, for terrestrial mammals, of glacial refuges located south of the Black Sea and south of Caucasus (see Hewitt (1999), for a review). The case of $M$. macedonicus provides strong evidence for at least two such refuges: $2.9 \%$ divergence is substantial, and it seems very unlikely that it could result from an isolation-by-distance within a continuous population. The gene flow between our two subspecies has most probably been interrupted in the past. One outstanding question is whether or not there exists a transition zone between the two subspecies somewhere between Turkey and Israel and what is the nature of such a contact.

These two refuges may find their origin in the existence south of Caucasus and the Black Sea of large mountain ranges often over $1000 \mathrm{~m}$ altitude that spread continuously from the Zagross mountains in eastern Iran to the Pontic chain and the Taurus mountains in Turkey, as shown in Figure 1. During the glacial maximum, favourable climatic pockets may have persisted in the lowlands backed by the south facing slopes of the Caucasus, especially in those places where the climate was ameliorated by the influence of the Black, or Caspian water bodies. Note that on Figure 1 the refuge south of the Caucasus is presented as a single circle, although it may well have been limited to one or the other coastal plains. During recolonisation, the northern subspecies $M$. m. macedonicus would have extended its range rapidly westwards to Europe through the coastal plain of the Black Sea whose level was lower than at present (Ryan et al, 1997; Aksu et al, 1999). One question may be why the subspecies halted expansion at the low hills $(<700 \mathrm{~m})$ of 
the Balkans. The answer may be that they faced competitive exclusion (Ivantcheva and Cassaing, 1999) with the northern species $M$. spicilegus, the mound building mouse, which probably arrived along the northern shores of the Black Sea from a refugium that may well have been located around the Crimean Peninsula. This competitive exclusion is also supported by the fact that $M$. macedonicus and M. spicilegus are found interacting sympatrically only in a very localised place, as mentioned in Bonhomme (1986). Indeed, two individuals from the former species and 13 from the latter where caught in the same trap line, in a maize field near Kranevo (Bulgaria) in the costal plain bordering the Black Sea (Bonhomme et al, 1983, unpublished observation).

As to the southern subspecies $M$. m. spretoides, there is fossil evidence of its presence in the Levant thoughout the last interglacial and glacial period (Auffray et al (1988) and references cited therein). It may have thus been established south of Zagross and Taurus chains (Figure 1) in what would constitute a larger refuge extending eventually down to the Nile.

\section{Acknowledgements}

Eviatar Nevo and Tamar Krugman (Institute of Evolution of University of Haifa) for assistance in the field, Vincent Debat and Laurent Fabre for trapping animals in Israel, and the team of late N. N. Vorontsov lab for field work in Georgia. This study was supported in part by GDR 2474 CNRS and a grant from Programme CNRS Paléoenvironnement "Connaissance du Concept d'Anthropisation: Stress subis par les populations actuelles et fossiles sous l'effet de l'anthropisation", to J.-C. A. and by UMR 5000. This is publication ISEM 2002-021

\section{References}

Aksu A, Hiscott RN, Yasar D (1999). Oscillating Quatenary water levels of the Marmara Sea and vigorous outflow into the Aegean sea from the Marmara Sea-Black Sea drainage corridor. Marine Geol 153: 275-302.

Auffray J-C, Tchernov E, Bonhomme F, Heth G, Simson S, Nevo E (1990). Presence and ecological distribution of "Mus spretoides" and Mus musculus domesticus in Israel. CircumMediterranean vicariance in the genus Mus. Zeitschrift für Saügetierkunde 55: 1-10.

Auffray J-C, Tchernov E, Nevo E (1988). Origine du commensalisme de la souris domestique (Mus musculus domesticus) visà-vis de l'homme. CR Acad Sci Paris 307: 517-522.

Bates PJJ, Harrison D (1989). New records of small mammals from Jordan. Bonn Zool Beitr 40: 223-226.

Bibb MJ, Van Etten RA, Wright CT, Walberg MW, Clayton DA (1981). Sequence and gene organisation of mouse mitochondrial DNA. Cell 26: 176-180.

Bonhomme F (1986). Evolutionary relationships in the Genus Mus. In: Potter M, Nadeau JH, Cancro MP (eds) The Wild Mouse in Immunology, Springer-Verlage: Berlin. pp 19-34.

Bonhomme F, Catalan J, Gerasimov S, Orsini P, Thaler L (1983). Le complexe d'espèce du genre Mus en Europe Centrale et Orientale. Zeitschrift für Saügetierkunde 48: 78-85.

Boursot P, Auffray J-C, Britton-Davidian J, Bonhomme F (1993). The evolution of house mice. Ann Rev Ecol Syst 24: 119-152.

Felsenstein J (1993). Phylogeny inference package. Department of Genetics, University of Washington, Seattle.

Gerasimov S, Nikolov H, Mihailovav, Auffray J-C, Bonhomme F (1990). Morphometric stepwise discriminant analysis of the five genetically determined European taxa of the genus Mus. Biol J Lin Soc 41: 47-64.

Gündüz I, Tez C, Malikov V, Vaziri A, Polyakov AV, Searle JB (2000). Mitochondrial DNA and chromosomal studies of wild mice (Mus) from Turkey and Iran. Heredity 84: 458-467.

Harrison D, Bates J (1991). The Mammals of Arabia. 2nd edition. Harrison Zoological Museum: Kent.

Hewitt GM (1999). Post-glacial re-colonization of European biota. Biol J Lin Soc 68: 87-112.

Ivantcheva A, Cassaing J (1999). Male-female interactions and socio-sexual isolation of Mus spicilegus toward two other species of east-European mice. M. macedonicus and M. m. musculus. CR Acad Sci III 322: 597-605.

Ivanitskaya E, Gorlov I, Gorlov O, Nevo E (1996). Chromosome markers for Mus macedonicus (Rodentia, Muridae) from Israel. Hereditas 124: 145-150.

Krystufek B, Macholan M (1998). Morphological differentiation in Mus spicilegus and the taxonomic status of mound-building mice from the Adriatic coast of Yugosliava. J Zool Lond 245: 185-196.

Orth A, Lyapunova E, Kandaurov A, Boissinot S, Boursot P, Vorontsov N et al (1996). L'espèce polytypique Mus musculus en Transcaucasie. C.R.A.S. série III. Paris 5.

Petrov B, Ruzic A (1983). Preliminary report of the taxonomical status of the members of the genus Mus in Yugoslavia with description of a new subspecies $M$. hortulanus macedonicus (sub. nova). In: Proceedings on the Fauna of SR Serbia, Serbian Academy of Sciences and Arts, Belgrade 2: 175-178.

Rohlf F-J, Slice D (1990). Extensions of the Procrustes method for the optimal superimposition of landmarks. Syst Zool 39: 40-59.

Ryan W, Pitman II W, Major C, Shiimkus K, Moskalenko V, Jones GA, Dimitrov P (1997). An abrupt drowning of the Black sea shelf. Marine Geol 138: 119-126.

Seddon JM, Santucci F, Reeve NJ, Hewitt GM (2001). DNA footprints of European hedgehogs, Erinaceus europaeus and E. concolor: Pleistocene refugia, postglacial expansion and colonization routes. Mol Ecol 10: 2187-2198. 